\title{
How safe is the semi-sterile technique in the percutaneous pinning of supracondylar humerus fractures?
}

\author{
Ali Turgut, M.D., Burak Önvural, M.D., Cemal Kazımoğlu, M.D., \\ Tayfun Bacaksız, M.D., Önder Kalenderer, Haluk Ağuş, M.D. \\ Department of Orthopaedics and Traumatology, Tepecik Training and Research Hospital, İzmir-Turkey
}

\begin{abstract}
BACKGROUND: The purpose of the present study was to evaluate safety and efficiency of the semi-sterile technique used in recent years in treatment of pediatric supracondylar humeral fractures (SHF).

METHODS: Total of 712 patients who were treated for SHF via closed reduction and percutaneous fixation with semi-sterile technique were enrolled in present study. Patients were evaluated for postoperative infection and other complications. Clinical and radiological assessments were also made.

RESULTS: It was found that there were 52 (7.3\%) pin tract infections, which responded to oral antibiotic administration and pin care without need for early pin removal (before 3 weeks). There were no deep infections. Loss of reduction was observed in 82 patients (I I.5\%). There were 59 iatrogenic nerve injuries (8.3\%), of which 52 (7.3\%) were ulnar palsy. Clinically apparent cubitus varus was observed in 29 (4.1\%) patients.
\end{abstract}

CONCLUSION: Though semi-sterile technique is an effective treatment in closed percutaneous pinning of SHF, increased pin tract infection risk is a matter of concern.

Keywords: Pin tract infection; semi-sterile technique; supracondylar humerus fracture.

\section{INTRODUCTION}

Supracondylar humeral fractures (SHF) are the most common elbow fractures in children. ${ }^{[1]}$ Current treatment choice for supracondylar fractures is closed reduction and percutaneous pin fixation with fluoroscopic guidance. ${ }^{[2-6]}$ Semi-sterile pin fixation technique has been reported as alternative treatment modality that saves time, costs, and materials without resulting increased infection risk. ${ }^{[7]}$ Bashyal et al. concluded that limited preparation with towel draping to treat SHF has low infection rate. It was stated that neither full preparation and draping nor preoperative prophylactic antibiotic administration seems to be advantageous. ${ }^{[8]}$

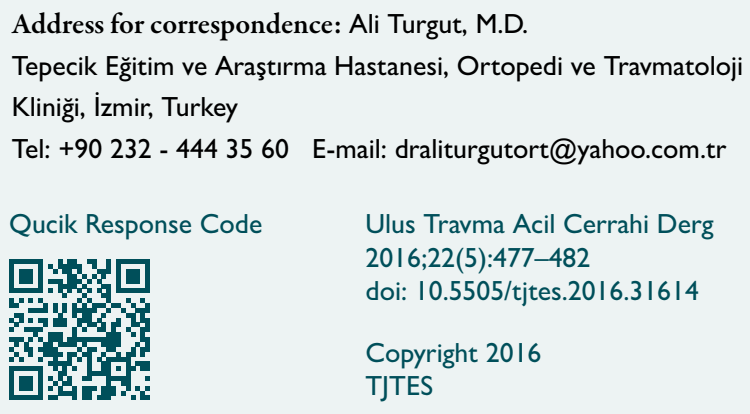

Though full surgical preparation and draping is thought to be standard care, studies are encouraging use of semi-sterile technique because of the savings it offers. Our hospital is a referral center for pediatric trauma patients, especially outside of typical work hours. Preference is to operate on $\mathrm{SHF}$ as an urgent case as soon as possible. Some nights, 5 or 6 patients may require surgery. Heavy workload of hospital surgical department makes saving time very important. Semisterile surgical technique has been in use at our hospital since 2008.

Present study was designed to determine if semi-sterile technique is really as safe as has been reported by conducting retrospective review of efficacy and safety of semi-sterile pin fixation technique in treatment of SHF in children.

\section{MATERIALS AND METHODS}

Retrospective analysis of database of patients treated for SHF in our training and research hospital between January 2009 and December 2013 was performed. More reliable digital archive of hospital available as of 2009 determined earliest records used. Study was approved by local ethics committee (12.05.2015/number:4). Inclusion criteria were skeletal immaturity, at least 6 months of follow-up, and treatment using 
closed reduction and percutaneous pinning (CRPP). Exclusion criteria were open fracture, necessity for open surgery, ipsilateral fracture, or flexion-type fracture pattern. Of initial total of 767 patients, 7 patients had open fractures, 5 required open reduction, 17 had flexion-type injury, 4 patients had ipsilateral distal radius fracture, and 22 patients were lost to follow-up before pin removal and therefore excluded. The present study is an evaluation of data of 712 patients.

Preoperative and follow-up radiographs of patients were reviewed to determine type of fracture, treatment type (lateral or cross-pinned) and Baumann angle ${ }^{[9]}$ measurement. Outpatient clinic records were evaluated for follow-up duration, length of hospitalization, iatrogenic nerve injuries, patient complaints, deformity, pin site infection and treatment, and physical examination notes.

\section{Surgical Technique and Postoperative Care}

Ketamine $\left(\operatorname{Ketalar}^{\circledR}\right)$ anesthesia was used for all patients, and all were in supine position on operating table. All procedures were performed by a senior resident and a mid-level (more than I year in training) resident under guidance of surgeon. Fracture was reduced by one of the residents with guidance of fluoroscopy (Figure la) while wearing non-sterile gloves. After confirmation of reduction, second resident maintained reduction and rotated arm internally to allow surgeon to pass Kirschner wires (K-wire) laterally while on image intensifier. If malrotation of fracture was present, it was corrected by second resident with internal rotation of proximal fragment. The first resident wore sterile gloves at this step and placed sterile towel and dressings on image intensifier. After selecting appropriate diameter of K-wire, first resident fastened it to the drill. Beginning at lateral epicondyle, $10 \%$ povidone-iodine solution was applied in ever-widening circles until circle of at least $5 \mathrm{~cm}$ in diameter was saturated (Figure $\mathrm{Ib}$ ). lodine solution was allowed to dry on skin for at least I minute. Two K-wires were passed laterally under fluoroscopic guidance (Figure Ic). Two lateral K-wires were used in parallel if third K-wire was used medially to prevent rotation of distal fragment. If fracture was Type II and only lateral fixation was required, K-wires were passed in divergent fashion. If crossed pin configuration was used, same protocol was applied at medial side of elbow using medial epicondyle as reference point for the circle (Figure Id). Single wire was then passed medially with lessening flexion of elbow to minimize anterior subluxation of ulnar nerve (Figure le). One of laterally inserted wires was removed if fracture was thought to be stable. Final position of fixed fracture was confirmed (Figures $2 a$ and $b$ ).

All patients received single dose of prophylactic antibiotic regimen before procedure (cefazolin sodium [Cefozin ${ }^{\circledR}$ ] 25 $\mathrm{mg} / \mathrm{kg}$, intravenously). Pins were left protruding through skin with bent end for easy removal. Long arm cast with approximately $70^{\circ}$ to $90^{\circ}$ of elbow flexion or splint was applied in operating room. Patients did not receive antibiotics after surgery and antibiotic medication was not prescribed after hospital discharge. Parents of patients were told to visit family physician in every 4 days for pin site care until pins were removed.

Postoperative clinical and radiographic evaluations were performed at I week, 3 to 4 weeks, and 3 months. Cast and pins were removed at third or fourth week follow-up as outpatient procedure according to radiological indication of
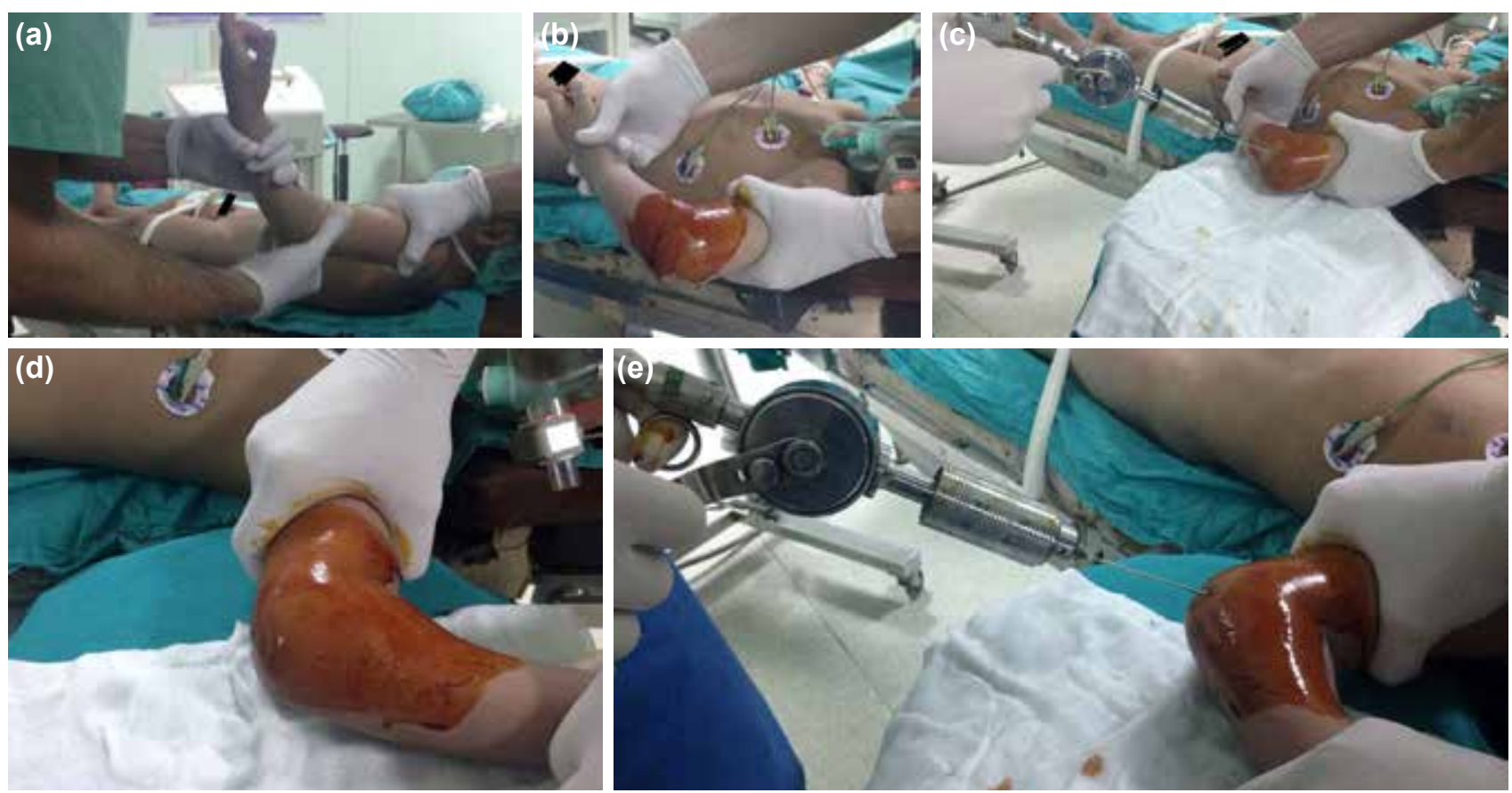

Figure 1. (a) Reduction of the fracture with non-sterile gloves. (b) Preparation of lateral side of the elbow with povidon-iodine. (c) Passing Kirschner wires laterally. (d) Preparation of medial side of the elbow with povidon-iodine. (e) Passing Kirschner wire medially. 

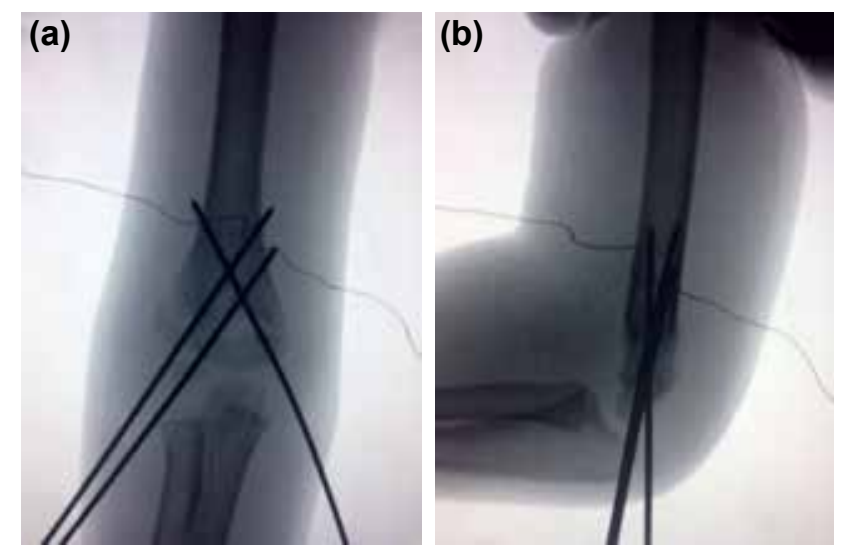

Figure 2. (a) Antero-posterior fluoroscopy view of the reduced and fixed fracture. (b) Lateral fluoroscopy view of the reduced and fixed fracture.

fracture healing. Humeral-ulnar carrying angle was evaluated radiologically, and clinical assessment was made for flexion and extension degree according to Flynn's criteria. ${ }^{[10]}$ Patient's uninjured side was compared with injured site radiologically and clinically at 6-month intervals. Baumann angle of intraoperative or immediate postoperative anteroposterior radiograph was compared with angle on radiograph taken at time of fracture union (approximately third week) to determine any reduction loss. Any degree of difference in this angle was accepted as loss of reduction in coronal plane. Failure of anterior humeral line to intersect capitellar physis was accepted as loss of reduction in sagittal plane.
SPSS software (version 21.0; SPSS Inc., Chicago, IL, USA) was used for statistical analysis. Patients were divided into 2 groups according to fracture type (type II or type III-IV), pin configuration (only laterally or cross-pinned) and gender (male or female). Complication rates of groups were compared using chi-squared test and $\mathrm{p}<0.05$ was considered statistically significant.

\section{RESULTS}

Mean follow-up of patients was 23.6 months (range: 6-44 months). Average hospitalization period was 2 days (range: 1-6 days). Patient demographic and fracture- related data are presented in detail in Table I. Pin tract infections, which responded well to oral antibiotic treatment and local pin site care without requiring early pin removal, occurred in 52 (7.3\%) patients. There was no deep infection (serious discharge and localized erythema) or osteomyelitis (Table 2). There was no reoperation for loss of reduction or other reason. Based on criteria of Flynn et al., 8 patients (I.12\%) had fair or poor result due to varus angulation, with excellent functional outcome in 6 . Two patients with fair results had significant loss of range of motion at final follow-up; 82 (11.5\%) patients had reduction loss in coronal plane at final follow-up. There was no incidence of loss of reduction in sagittal plane. Among those with reduction loss in coronal plane, only 29 patients had clinically noticeable cubitus varus deformity. Average change in Baumann angle was $2.5^{\circ}$ (range: $0-5^{\circ}$ ). No patient had major loss of reduction; greatest dif-

Table I. Patient demographic and fracture-related data

\begin{tabular}{|c|c|c|c|c|c|c|c|c|}
\hline \multirow[t]{2}{*}{ Fracture type } & \multicolumn{2}{|c|}{ II } & \multicolumn{2}{|c|}{ III } & \multicolumn{2}{|c|}{ IV } & \multicolumn{2}{|c|}{ Total } \\
\hline & $\mathbf{n}$ & $\%$ & $\mathbf{n}$ & $\%$ & $\mathbf{n}$ & $\%$ & $\mathbf{n}$ & $\%$ \\
\hline \multicolumn{9}{|l|}{ Gender of patients } \\
\hline Male & 222 & 55 & $15 \mid$ & 56 & 29 & 61 & 402 & 56.5 \\
\hline Female & 176 & 45 & 116 & 44 & 18 & 39 & 310 & 43.5 \\
\hline Number of patients & 398 & 56 & 267 & 37.5 & 47 & 6.5 & 712 & 100 \\
\hline
\end{tabular}

Table 2. Total complications

\begin{tabular}{lcc}
\hline Complication & Number of patients & Ratio (\%) \\
\hline Loss of reduction & 82 & 11.5 \\
Clinically apparent cubitus varus & 29 & 4.1 \\
Superficial/pin site infection & 52 & 7.3 \\
Deep infection/osteomyelitis & & \\
latrogenic nerve injury (sensorial or motor) & & \\
$\quad$ Ulnar nerve & 52 & 7.3 \\
$\quad$ Median nerve & 4 & 0.6 \\
$\quad$ Radial nerve & 3 & 0.4 \\
\hline
\end{tabular}


Table 3. Statistical analysis of each complication according to group

\begin{tabular}{|c|c|c|c|c|c|c|c|c|c|c|c|c|}
\hline & $\begin{array}{c}\text { Pin tract } \\
\text { infection } \\
\quad(n / n)\end{array}$ & $\mathbf{p}^{*}$ & $\begin{array}{c}\text { Cubitus } \\
\text { varus } \\
\text { (n/n) }\end{array}$ & $\mathbf{p}^{*}$ & $\begin{array}{l}\text { Loss of } \\
\text { reduction } \\
(\mathbf{n} / \mathbf{n})\end{array}$ & $\mathbf{p}^{*}$ & $\begin{array}{c}\text { Ulnar nerve } \\
\text { injury } \\
\text { (n/n) }\end{array}$ & $\mathbf{p}^{*}$ & $\begin{array}{c}\text { Median nerve } \\
\text { injury } \\
(\mathbf{n} / \mathbf{n})\end{array}$ & $\mathbf{p}^{*}$ & $\begin{array}{c}\text { Radial nerve } \\
\text { injury } \\
(\mathbf{n} / \mathbf{n})\end{array}$ & $\mathbf{p}^{*}$ \\
\hline $\begin{array}{l}\text { Type II } \\
\text { fracture/type III-IV } \\
\text { fracture }(398 / 3 \mid 4)\end{array}$ & $18 / 34$ & 0.001 & $7 / 22$ & $<0.001$ & $18 / 64$ & $<0.001$ & $9 / 43$ & $<0.001$ & $1 / 3$ & 0.21 & $2 / 1$ & 0.70 \\
\hline $\begin{array}{l}\text { Laterally } \\
\text { pinned/cross- } \\
\text { pinned (184/528) }\end{array}$ & $9 / 43$ & 0.14 & $7 / 22$ & 0.83 & $14 / 68$ & 0.54 & $0 / 52$ & $<0.001$ & $1 / 3$ & 0.96 & $0 / 3$ & 0.30 \\
\hline $\begin{array}{l}\text { Male/female } \\
(402 / 310)\end{array}$ & $25 / 27$ & 0.32 & $17 / 12$ & 0.81 & $4 I / 4 I$ & 0.21 & $28 / 24$ & 0.49 & $2 / 2$ & 0.32 & $\mathrm{I} / 2$ & 0.58 \\
\hline
\end{tabular}

*Chi-squared test.

ference between perioperative and final Baumann angle was $5^{\circ}$. There was total of 59 nerve injuries (52 ulnar, 4 median, 3 radial nerve) in 57 patients $(8.0 \%)$ that were not recorded preoperatively. Crossed pin configuration was used in all patients who had ulnar nerve injury (52 of 590 patients [8.8\%]). $\mathrm{K}$-wires were removed after confirmation of fracture healing, including patients with iatrogenic ulnar nerve injury. All ulnar nerve injuries recovered without any further treatment in average of $2 \frac{1}{2}$ months (range: $1-7$ months).

There were 398 patients with type II fracture and 314 patients with type III or type IV fracture. Fractures were pinned only laterally in 184 patients who had type II fracture. Pin tract infection, loss of reduction, cubitus varus deformity, and iatrogenic ulnar nerve injury complication ratios were statistically significantly higher in patients with type III or type IV fracture $(p=0.00 \mathrm{I},<0.00 \mathrm{I},<0.00 \mathrm{I},<0.00 \mathrm{I}$, respectively). latrogenic ulnar nerve injury was also statistically significantly higher in cross-pinned group, as expected $(\mathrm{p}=<0.00 \mathrm{I})$ (Table $3)$. There was no significant difference in complication rate according to patient gender.

\section{DISCUSSION}

lobst et al. were first to report that semi-sterile technique was safe and efficient method in a study with 304 consecutive patients. Authors stated that procedure is very safe with regard to infection risk, reporting no patients with superficial or deep infections. Present series includes more than double the number of patients compared to Lobst study. Superficial infection rate of $7.22 \%$ was observed, which is considerably higher than less than I and 6\% reported in current literature, which adds to risk of infection. ${ }^{[1-16]}$ From an observational point of view, authors acknowledge that many parents of our patients are not precise in following recommendations for pin tract care following K-wire fixation; however, this is not enough to explain high superficial infection rate in present series. It is thought that it may be attributed at least partially to semi-sterile technique.
Despite fact that all infections were brought under control without serious complications, for medical and legal reasons, surgeons should be aware of high superficial infection rates. Fowles et al. ${ }^{[17]}$ reported approximately $3 \%$ significant infection requiring more than oral antibiotic treatment in their series. Deep infection or septic arthritis is devastating complication after pin tract infection, and may lead to serious consequences. Condition of operating room and education of personnel are important issues that must be keep in mind during semi-sterile pin application, especially in developing countries. lobst et al. described procedure as similar to setup used for placing traction pin at bedside. However, it is important to be aware that pins used for supracondylar fracture directly encounter fracture hematoma several times, jeopardizing the procedure. Therefore, authors do not agree that perioperative antibiotics in association with percutaneous pinning of supracondylar humerus fractures are not necessary.

Pin tract infections were significantly lower in patients with relatively less unstable fractures in present study group. Surgery duration was not included in hospital records, but it is thought that duration of pinning of unstable fracture is longer. Therefore, higher infection rates may be due in part to prolonged length of procedure. We found no significant difference in infection rate according to pin configuration in present study group.

Literature information about pin site infection is primarily based on retrospectively designed studies using recorded physical examination notes, as present study did. In a very recent study, Kao et al. ${ }^{[18]}$ prospectively compared daily pin care and no pin care in patients with SHF who were treated using CRPP. Method of skin preparation was not mentioned, but it was stated that all patients received prophylactic antibiotic cefazolin sodium $30 \mathrm{mg} / \mathrm{dL}$. Interestingly, pin site infections, which were mostly low grade, were reported in $53.3 \%$ of non-care group patients and $90.3 \%$ of daily care group 
patients. Given these findings, it would seem that perhaps physical examination records are not being kept adequately.

Injury to ulnar nerve has been reported to range from $1.4 \%$ to $20 \%{ }^{[19]}$ Lyons et al. ${ }^{[20]}$ and Kalenderer et al. ${ }^{[1]}$ reported $5 \%$ and $5.2 \%$ iatrogenic ulnar nerve injuries in 375 and 473 patients, respectively. lobst et al. ${ }^{[7]}$ reported nerve injuries in 20 patients $(6.6 \%)$ they treated with semi-sterile technique. In present study, iatrogenic ulnar nerve injury was observed in $7.3 \%(52 / 7 / 2)$ of patients. It is the opinion of the authors that this could be minimalized if mini-open technique described by Green et al. ${ }^{[22]}$ is used, but it is inappropriate to use this technique in semi-sterile conditions. Shtarker et al. ${ }^{[19]}$ used ulnar nerve monitoring to avoid iatrogenic nerve injury for medial pin insertion and stated that there were no iatrogenic ulnar nerve injuries in 138 patients. Similarly, nerve monitoring is not appropriate for semi-sterile conditions. It is a drawback of semi-sterile technique. Flexion of elbow was reduced and $\mathrm{K}$-wire was inserted from medial epicondyle instead of ulnar groove to minimize risk of iatrogenic injury in present study patient group.

Loss of reduction has been reported in $20-30 \%$ of conservatively treated type II and III SHF and $2.9-18.2 \%$ of surgically treated patients. ${ }^{[1,23]}$ Sankar et al. stated that loss of reduction can be expected if bicortical fixation of 2 or more pins is not achieved, if there is inadequate pin separation $(>2 \mathrm{~mm})$ at fracture site, or if 2 or more wires do not pass through both fragments. ${ }^{[24]}$ In a very recent study, Pennock et al. ${ }^{[25]}$ concluded that primary factor responsible for loss of reduction is inadequate pin separation. It was recommended that there be at least $13 \mathrm{~mm}$ between wires, or one-third of width of humerus at level of fracture. Reduction loss was observed in $1 \mathrm{I} .5 \%$ of patients in present study. This ratio is higher than many previously published data. ${ }^{[1,24,25]}$ Use of any change of Baumann angle as criterion for loss of reduction likely explains high rate, since all instances of loss of reduction were mild (less than $5^{\circ}$ in Baumann angle). Higher rate of loss of reduction in patients with type III and IV fractures is probably due to comminution of fracture or lack of stability obtained with intact periosteum.

The most common deformity following SHF is cubitus varus. Commonly accepted criteria for significant coronal plane deformity is change of $>12^{\circ}$ in Baumann angle. ${ }^{[26]}$ Clinically apparent cubitus varus deformity was observed in 29 patients (4.1\%) in present study. As greatest change in Baumann angle was $5^{\circ}$ in present study group, it is thought that intraoperative reduction in these 29 patients was due to prior varus position. Tellisi et al. reported up to $6.6 \%$ cubitus varus deformity. ${ }^{[27]}$ In a recent study, Or et al. ${ }^{[26]}$ stated that they had observed malalignment in 20 out of 396 (5.05\%) patients. Present study results are compatible with the literature.

Present study authors now annually treat more than 200 supracondylar fractures surgically. Transferring supracon- dylar fractures to advanced facilities or trauma centers has become a trend in recent years. As a result, large hospitals have a workload beyond their capacity. Semi-sterile technique provides means to operate on supracondylar fractures as emergency case in these busy centers. As open surgery for supracondylar fractures is rarely performed in our clinic, semi-sterile technique is very practical and suitable method. Procedure is significantly quicker and less expensive than full sterile preparation of patient.

There are several limitations to this study. Study design is retrospective; confounding factors and cost analysis, which would be more valid in control-based analysis, were not studied; and surgery duration data could not be evaluated.

In conclusion, semi-sterile technique is an alternative treatment modality in management of SHF in children; however, substantial increase in superficial pin tract infections is a concern. Patients must be strictly monitored if this technique is preferred.

Conflict of interest: None declared.

\section{REFERENCES}

1. Zorrilla S de Neira J, Prada-Cañizares A, Marti-Ciruelos R, PretellMazzini J. Supracondylar humeral fractures in children: current concepts for management and prognosis. Int Orthop 2015;39:2287-96. Crossref

2. Bombaci H, Gereli A, Küçükyazici O, Görgeç M, Deniz G. The effect of surgical exposure on the clinic outcomes of supracondylar humerus fractures in children. [Article in Turkish] Ulus Travma Acil Cerrahi Derg 2007;13:49-54.

3. Herring JA. Upper extremity injuries. In: Herring JA, ed. Tachdjian's Pediatric Orthopaedics. Philadelphia, PA: W.B. Saunders 2002:2139-68.

4. Kasser JR, Beaty JH. Supracondylar fractures of the distal humerus. In: Beaty JH, Kasser JR, eds. Fractures in Children. Philadelphia, PA: Lippincott Williams \& Wilkins 2001:577Y624.

5. de las Heras J, Durán D, de la Cerda J, Romanillos O, Martínez-Miranda J, Rodríguez-Merchán EC. Supracondylar fractures of the humerus in children. Clin Orthop Relat Res 2005;432:57-64. Crossref

6. Kazimoglu C, Cetin M, Sener M, Aguș H, Kalanderer O. Operative management of type III extension supracondylar fractures in children. Int Orthop 2009;33:1089-94. Crossref

7. Iobst CA, Spurdle C, King WF, Lopez M. Percutaneous pinning of pediatric supracondylar humerus fractures with the semisterile technique: the Miami experience. J Pediatr Orthop 2007;27:17-22. Crossref

8. Bashyal RK, Chu JY, Schoenecker PL, Dobbs MB, Luhmann SJ, Gordon JE. Complications after pinning of supracondylar distal humerus fractures. J Pediatr Orthop 2009;29:704-8. Crossref

9. Baumann E. On the treatment of fractures of the elbow joint. [Article in German] Langenbecks Arch Klin Chir Ver Dtsch Z Chir 1960;295:3004. [Abstract]

10. Flynn JC, Matthews JG, Benoit RL. Blind pinning of displaced supracondylar fractures of the humerus in children. Sixteen years' experience with long-term follow-up. J Bone Joint Surg Am 1974;56:263-72.

11. Reynolds RA, Mirzayan R. A technique to determine proper pin placement of crossed pins in supracondylar fractures of the elbow. J Pediatr Orthop 2000;20:485-9. Crossref 
12. Ponce BA, Hedequist DJ, Zurakowski D, Atkinson CC, Waters PM. Complications and timing of follow-up after closed reduction and percutaneous pinning of supracondylar humerus fractures: follow-up after percutaneous pinning of supracondylar humerus fractures. J Pediatr Orthop 2004;24:610-4. Crossref

13. Shannon FJ, Mohan P, Chacko J, D'Souza LG. “Dorgan's” percutaneous lateral cross-wiring of supracondylar fractures of the humerus in children. J Pediatr Orthop 2004;24:376-9. Crossref

14. Skaggs DL, Cluck MW, Mostofi A, Flynn JM, Kay RM. Lateral-entry pin fixation in the management of supracondylar fractures in children. J Bone Joint Surg Am 2004;86:702-7.

15. Topping RE, Blanco JS, Davis TJ. Clinical evaluation of crossed-pin versus lateral-pin fixation in displaced supracondylar humerus fractures. J Pediatr Orthop. 1995;15:435-9. Crossref

16. Meyer CL, Kozin SH, Herman MJ, Safier S, Abzug JM. Complications of pediatric supracondylar humeral fractures. Instr Course Lect 2015;64:483-91.

17. Fowles JV, Kassab MT. Displaced supracondylar fractures of the elbow in children. A report on the fixation of extension and flexion fractures by two lateral percutaneous pins. J Bone Joint Surg Br 1974;56:490-500.

18. Kao HK, Chen MC, Lee WC, Yang WE, Chang $\mathrm{CH}$. A prospective comparative study of pin site infection in pediatric supracondylar humeral fractures: daily pin care vs. no pin care. Arch Orthop Trauma Surg 2014;134:919-23. Crossref

19. Shtarker H, Elboim-Gabyzon M, Bathish E, Laufer Y, Rahamimov N, Volpin G. Ulnar nerve monitoring during percutaneous pinning of supracondylar fractures in children. J Pediatr Orthop 2014;34:161-5. Crossref
20. Lyons JP, Ashley E, Hoffer MM. Ulnar nerve palsies after percutaneous cross-pinning of supracondylar fractures in children's elbows. J Pediatr Orthop 1998;18:43-5. Crossref

21. Kalenderer O, Reisoglu A, Surer L, Agus H. How should one treat iatrogenic ulnar injury after closed reduction and percutaneous pinning of paediatric supracondylar humeral fractures? Injury 2008;39:463-6.

22. Green DW, Widmann RF, Frank JS, Gardner MJ. Low incidence of ulnar nerve injury with crossed pin placement for pediatric supracondylar humerus fractures using a mini-open technique. J Orthop Trauma 2005;19:158-63. Crossref

23. Balakumar B, Madhuri V. A retrospective analysis of loss of reduction in operated supracondylar humerus fractures. Indian J Orthop 2012;46:690-7. Crossref

24. Sankar WN, Hebela NM, Skaggs DL, Flynn JM. Loss of pin fixation in displaced supracondylar humeral fractures in children: causes and prevention. J Bone Joint Surg Am 2007;89:713-7. Crossref

25. Pennock AT, Charles M, Moor M, Bastrom TP, Newton PO. Potential causes of loss of reduction in supracondylar humerus fractures. J Pediatr Orthop 2014;34:691-7. Crossref

26. Or O, Weil Y, Simanovsky N, Panski A, Goldman V, Lamdan R. The outcome of early revision of malaligned pediatric supracondylar humerus fractures. Injury 2015;46:1585-90. Crossref

27. Tellisi N, Abusetta G, Day M, Hamid A, Ashammakhi N, Wahab $\mathrm{KH}$. Management of Gartland's type III supracondylar fractures of the humerus in children: the role audit and practice guidelines. Injury 2004;35:1167-71. Crossref

\section{ORİIINAL ÇALIŞMA - ÖZET}

\section{Suprakondiler humerus kırıklarının perkütan tellenmesinde kısmi steril teknik ne kadar güvenlidir?}

\section{Dr. Ali Turgut, Dr. Burak Önvural, Dr. Cemal Kazımoğlu, Dr. Tayfun Bacaksız, Dr. Önder Kalenderer, Dr. Haluk Ağuş}

Tepecik Eğitim ve Araştırma Hastanesi, Ortopedi ve Travmatoloji Kliniği, İzmir

AMAÇ: Kısmi steril teknik, çocuk suprakondiler humerus kırıklarının tedavisinde son yıllarda kullanılır hale gelmiştir. Bu çalışmanın amacı bu tekniğin suprakondiler humerus kırıklarının tedavisindeki güvenilirlik ve etkinliğinin araştırılmasıdır.

GEREÇ VE YÖNTEM: Bu çalışmaya, kısmi steril teknik kullanılarak kapalı redüksiyon ve fiksasyon uygulanan 7ı 2 hasta dahil edildi. Hastalar ameliyat sonrası oluşabilecek olan enfeksiyon ve diğer komplikasyonlar açısından değerlendirildi. Klinik ve radyolojik değerlendirmeler yapıldı.

BULGULAR: Elli iki hastada (\%7.22), ağızdan antibiyotik tedavisi ve tel dibi bakımına cevap veren erken tel çekilmesini (üç hafta öncesi) gerektirmeyen çivi yolu enfeksiyonu izlendi. Derin enfeksiyon ile karşılaşılmadı. Redüksiyon kaybı ile 82 hastada (\% I I.5) karşılaşıldı. Elli iki tanesi (\%7.3) ulnar sinir olmak üzere toplam 59 (\%8.3) iyatrojenik sinir yaralanması oluştu. Yirmi dokuz (\%4. I) hastada klinik olarak belirgin kubitus varus deformitesi vardı. TARTIŞMA: Kısmi steril teknik suprakondiler humerus kırıklarının tedavisinde etkiliymiş gibi görünmekteyse de artmış tel dibi enfeksiyon oranları kaygı vericidir.

Anahtar sözcükler: Kısmi steril teknik; suprakondiler humerus kırıkları; tel dibi enfeksiyonu.

Ulus Travma Acil Cerrahi Derg 2016;22(5):477-482 doi: 10.5505/tjtes.2016.31614 